\title{
Characterization of Summertime Aerosol Particles Collected at Subway Stations in Seoul, Korea Using Low-Z Particle Electron Probe X-ray Microanalysis
}

\author{
BoWha Kim, Hae-Jin Jung, Young-Chul Song, Mi-Jung Lee, HyeKyeong Kim, Jo-Chun Kim ${ }^{1,2)}$, \\ Jongryeul Sohn ${ }^{3)}$ and Chul-Un Ro* \\ Department of Chemistry, Inha University, Incheon 402-751, Korea \\ ${ }^{1)}$ Department of Advanced Technology Fusion, Konkuk University, Seoul 143-701, Korea \\ ${ }^{2)}$ Department of Environmental Engineering, Konkuk University, Seoul 143-701, Korea \\ ${ }^{3)}$ Department of Environmental Health, College of Health Science Korea University, Seoul 136-703, Korea \\ *Corresponding author. Tel: +82-32-860-7676, E-mail: curo@inha.ac.kr
}

\begin{abstract}
A quantitative single particle analytical technique, denoted low- $Z$ particle electron probe $X$-ray microanalysis (low- $Z$ particle EPMA), was applied to characterize particulate matters collected at two underground subway stations, Jegidong and Yangje stations, in Seoul, Korea. To clearly identify the source of the indoor aerosols in the subway stations, four sets of samples were collected at four different locations within the subway stations: in the tunnel; at the platform; near the ticket office; nearby outdoors. Aerosol samples collected on stages 2 and $3\left(D_{p}: 10-\right.$ 2.5 $\mu \mathrm{m}$ and 2.5-1.0 $\mu \mathrm{m}$, respectively) in a 3-stage Dekati $\mathrm{PM}_{10}$ impactor were investigated. Samples were collected during summertime in 2009. The major chemical species observed in the subway particle samples were Fe-containing, carbonaceous, and soil-derived particles, and secondary aerosols such as nitrates and sulfates. Among them, Fe-containing particles were the most popular. The tunnel samples contained $85-88 \%$ of Fe-containing particles, with the abundance of Fe-containing particles decreasing as the distances of sampling locations from the tunnel increased. The Fe-containing subway particles were generated mainly from mechanical wear and friction processes at rail-wheel-brake interfaces. Carbonaceous, soil-derived, and secondary nitrate and/ or sulfate particles observed in the underground subway particles likely flowed in from the outdoor environment by human activities and the air-exchange between the subway system and the outdoors. In addition, since the platform screen doors (PSDs) limit air-mixing between the tunnel and the platform, samples collected at the platform at the Yangjae station (with PSDs) showed a marked decrease in the relative abundances of $\mathrm{Fe}$-containing particles
\end{abstract}

compared to the Jegidong station (without PSDs).

Key words: Subway particle, Low- $Z$ particle EPMA, Single particle analysis, Fe-containing particle, Aerosol analysis

\section{INTRODUCTION}

People spend most of their time indoors, either at home, in the workplace, or in transit, and concern over the air quality of indoor microenvironments and its influence on public health is ever increasing. Among the various types of indoor environments, underground subway stations are of great concern since many people living in metropolitan areas commute using underground subway transportation systems and thus spend considerable time in underground subway environments on a daily basis. The microenvironments in underground subway stations possess unique characteristics. First, subway stations have unique aerosol sources due to running trains. Furthermore, since many subway stations in metropolitan areas are underground, ventilation is sometimes limited. Therefore, subway aerosol particles tend to accumulate in a quasi-closed indoor environment and result in higher levels of indoor particulate matter (PM) than that of the outdoor atmosphere. Choi et al. (2004) reported that the average $\mathrm{PM}_{10}$ of subway stations in Seoul, Korea in 2000 was $182.9 \mu \mathrm{g} / \mathrm{m}^{3}$, exceeding the Korean standard of indoor $\mathrm{PM}_{10}$ of $150 \mu \mathrm{g} / \mathrm{m}^{3}$. Because of the high PM levels, as well as the possible adverse health effects of subway particles, there has been increasing attention upon air quality in underground subway systems.

There has been much research centering upon investigation of the chemical composition of subway aerosols. Salma et al. (2009) reported iron oxide as the 
major component in subway station samples collected in Budapest. Furthermore, for subway particles collected at worldwide underground subway systems, such as Helsinki, Buenos-Aires, and New York, iron $(\mathrm{Fe})$ was observed to be the major element with minor amounts of $\mathrm{Mn}, \mathrm{Cr}, \mathrm{Ni}, \mathrm{Cu}$, and $\mathrm{Zn}$ (Murruni et al., 2009; Nieuwenhuijsena et al., 2007; Aarino et al., 2005; Seaton et al., 2005; Chillrud et al., 2004). It was reported that the PM concentration and chemical composition of subway particles depend on various factors, such as train running frequency, ventilation system, break-pad composition, and the number of commuters (Park and Ha, 2008; Johansson and Johansson, 2003).

In general, the chemical compositions of PM are obtained by bulk analysis, with all the collected particles on the filter analyzed as a single sample. As a result, obtained results provide only an average composition of all the collected particles. Since airborne particles independently move and react in the air, it is necessary to apply a single particle analysis to obtain detailed information on physicochemical properties of the aerosol particles. Energy-dispersive electron probe X-ray microanalysis (ED-EPMA) is a powerful method for investigation of the physicochemical properties of individual microscopic aerosols. However, conventional ED-EPMA has a limitation for the analysis of atmospheric aerosol particles given its limited capability for determination of low- $Z$ elements such as carbon, nitrogen, and oxygen. This is a result of the Be window used for the protection of the energy-dispersive X-ray detector (EDX), which absorbs the lowenergy X-rays emitted from low- $Z$ elements and subsequently hinders their detection. However, by application of thin-window EDX and modified Monte Carlo calculations, a quantitative ED-EPMA, low- $Z$ particle EPMA allows for determination of the concentration of low-Z elements (Ro et al., 2003, 2000, 1999). Since the low- $Z$ particle EPMA can simultaneously provide information on the chemical compositions and morphology of individual particles, it has been applied for the characterization of various environmental aerosol samples such as Asian dust, urban aerosols, and Arctic aerosol (Geng et al., 2010; Kang et al., 2009; Hwang et al., 2008; Ro et al., 2005). Recently, Kang et al. (2008) extensively investigated subway particles collected at the Hyehwa subway station in Seoul, Korea, using low- $Z$ particle EPMA, where it was observed that $61-79 \%$ of collected subway particles were $\mathrm{Fe}$-containing particles generated mainly from mechanical wear and friction processes at rail-wheel-brake interfaces.

In this work, the summertime subway particles collected at two underground subway stations, the Jegi- dong and Yangjae stations, were analyzed using the low- $Z$ particle EPMA technique. To investigate the source of the subway particles, samples were collected at four different locations of the subway stations, including in the tunnel, at the platform, near the ticketing office, and outdoors. Since platform screen doors (PSDs), which limit air-mixing between the platform and the tunnel, were installed only in the Yangjae station, it was expected that different compositions of subway particles collected at the two stations would provide information for the role of PSDs. In this labs' previous work (Jung et al., 2010), the physicochemical properties of the wintertime subway particles at the Jegidong and the Yangjae stations were reported. In this work presented herein, the summertime subway particles collected at the two stations during July and August in 2009 were investigated.

\section{METHODS}

\section{1 Sampling}

Sampling of the subway particles was performed at the Jegidong and Yangjae stations in Seoul, Korea. Seoul is the capital of Korea and a densely populated megacity (population: 10.3 million; area: $605 \mathrm{~km}^{2}$ ). There are nine lines in the Seoul subway system. According to statistics provided from the Seoul metro transportation center (http://www.seoulmetro.co.kr), approximately 6.7 million commuters use the Seoul subway system on a daily basis. The Jegidong and Yangjae stations are underground subway stations in lines 1 and 2, respectively. Platform screen doors are installed between the tunnel and the platform at the Yangjae station and serve as full-height barriers between the station floor and ceiling; they are open only when the train stops at the platform. Subway samples were collected at three locations within the underground subway stations: in the tunnel; at the platform; near the ticket office. Outdoor aerosol samples were collected at street locations near the stations.

Sampling was done on July 22-24 and August 1113,2009 , for three consecutive days, once a day, in the Jegidong and Yangjae stations, respectively. A 3stage Dekati $\mathrm{PM}_{10}$ sampler was used for collection of the subway particles. The cut-off diameters for stages 1-3 of the Dekati $\mathrm{PM}_{10}$ sampler were 10, 2.5, and 1.0 $\mu \mathrm{m}$, respectively. The collected samples were put in plastic carriers, sealed, and stored in a desiccator.

\section{2 EPMA Measurements}

The measurements were carried out using a JEOL JSM-6390 scanning electron microscope (SEM) equipped with an Oxford Link SATW ultrathin window 
EDX detector, with a resolution of $133 \mathrm{eV}$ for $\mathrm{Mn}-\mathrm{K} \alpha$ X-rays. All X-ray spectra were recorded under the control of EMAX Oxford software. To achieve optimal experimental conditions, such as a low background level in the spectra and high sensitivity for low- $Z$ element analysis, a $10 \mathrm{kV}$ accelerating voltage was chosen. The beam current was $0.5 \mathrm{nA}$ for all measurements. In order to obtain a statistically sufficient number of counts in the X-ray spectra while limiting beam damage on sensitive particles, a typical measuring time of $10 \mathrm{~s}$ was employed. A more detailed discussion on the measurement conditions is given elsewhere (Ro et al., 1999). All X-ray data acquisitions for individual particles were carried out manually in point analysis mode, whereby the electron beam was focused at the center of each particle. Particles collected on stages 2 and $3\left(\mathrm{D}_{\mathrm{p}}: 10-2.5\right.$ and $2.5-1.0 \mu \mathrm{m}$, respectively) were analyzed for approximately 100 particles on each stage.

\section{3 Data Analysis}

From the measured X-ray spectrum for a particle, net X-ray intensities for chemical elements were extracted using the AXIL program (Vekemans et al., 1994). The elemental concentrations of individual particles were determined from their X-ray intensities by application of a Monte Carlo calculation combined with reverse successive approximations (Ro et al., 2003). When elemental concentrations in atomic fractions were obtained as $\mathrm{Ca} 20 \%$ : C 20\%: O 60\%, it indicated a particle composition of $\mathrm{Ca}, \mathrm{C}$, and $\mathrm{O}$, at a molar ratio of $1: 1: 3$. This particle was identified as $\mathrm{CaCO}_{3}$. However, it was rare to find atmospheric particles composed of only a single chemical species. Since most atmospheric particles were found as mixtures of two or more chemical species, a systematic methodology was necessary for speciation of individual particles. First, elements with less than $1.0 \%$ of atomic concentration were excluded from the procedure of chemical speciation. Since sample particles have a microscopic volume (pg range in mass for a single particle of micrometer size), elements at trace levels could not be reliably investigated. Second, if a particle was composed of a chemical species with more than $90 \%$ in its atomic fraction, the particle was regarded to be comprised of just one chemical species. Third, for particles internally mixed with two or more chemical species, particles were grouped according to abundant chemical species. For example, the notation of $\mathrm{FeO}_{\mathrm{x}} / \mathrm{Ca} / \mathrm{C}$ for a particle indicates that the major component of the particle was iron oxide $\left(\mathrm{FeO}_{\mathrm{x}}\right)$, with a considerable amount of $\mathrm{Ca}$ and $\mathrm{C}(>10$ atomic \%) included in the particle. Since hydrogen cannot be detected in EPMA, the organic component of the atmospheric aerosols cannot be specified. Therefore, particles were classified as carbonaceous particles when the sum of $\mathrm{C}, \mathrm{N}$, and $\mathrm{O}$ contents exceeded 90 atomic \%. The analytical procedures for determining chemical species classification are described in more detail elsewhere (Ro et al., 2003, 2000).

Since a number of particles have to be analyzed for a sample, an expert system capable of reliable chemical particle speciation was developed (Ro et al., 2004). The expert system mimics the logics used by experts and was implemented using macro programming available in MS Excel software. The system ran on IBMPC compatible computers and employed input and output files in the MS Excel format. Feasibility was verified for standard particles with known chemical compositions and for real atmospheric aerosols. By applying this expert system, the size-segregated number concentration of various chemical species could be obtained, the time necessary for the chemical speciation greatly shortened, and data containing detailed information could be saved and extracted later when more information was required for further analysis.

\section{RESULTS AND DISCUSSION}

\subsection{Physicochemical Properties of Subway Particles}

Fig. 1 shows typical secondary electron images for particles collected at different locations at the Yangjae station, such as in the tunnel, at the platform, at the ticket office, and outdoors, near the station. The chemical species for each particle obtained by low- $Z$ particle EPMA is denoted on the image. Iron oxide $\left(\mathrm{FeO}_{\mathrm{x}}\right)$ particles were the most frequently encountered subway particle, with carbonaceous and soil-derived particles the most popular for outdoor aerosols. All Fe-containing particles will be discussed in detail in the following section. As shown in Fig. 1, the morphology of the particles was quite distinguishable among particles with different chemical species. The Fe-containing particles were angular and irregular in shape, whereas carbonaceous particles (denoted as "C,N,O" in Fig. 1) appeared round in shape. The angular shape of the Fe-containing particles indicated they were generated mainly from mechanical wear and friction processes at rail-wheel-brake interfaces. Wear and friction processes initially produce iron metal particles, with surfaces sufficiently reactive towards oxygen in the air, resulting in the formation of iron oxides. Although some iron metal particles were encountered in subway particles, most of the $\mathrm{Fe}$-containing particles were found in the form of iron oxides. Some nano-sized Fecontaining particles agglomerated together to form a 

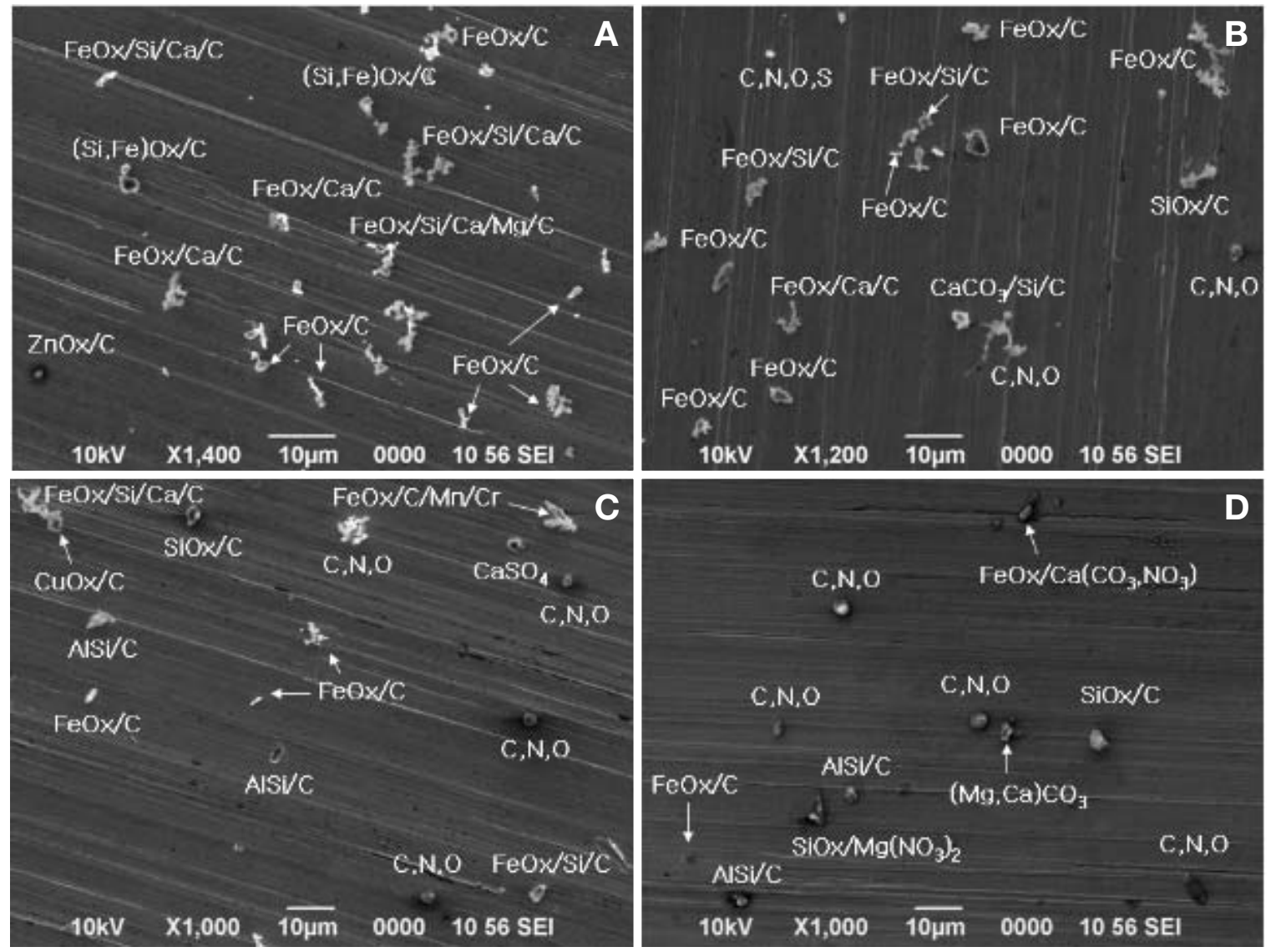

Fig. 1. Typical secondary electron images for particles collected in the Yangjae station: (A) in tunnel; (B) at platform; (C) near ticket office; (D) outdoors.

cluster. Those nano-sized particles were most likely formed by the condensation of gaseous iron species from the sparking between catenaries and pantographs attached to the trains (Kang et al., 2008). The existence of $\mathrm{Fe}$ as a minor element for almost all subway particles explains the generation of gaseous iron species in the subway environment.

Tables 1 and 2 show the relative abundance of particle types observed in the subway particle samples collected at the Jegidong and the Yangjae stations, respectively. The relative abundance of each particle type was obtained by dividing the number of each particle type by the total number of analyzed particles. Data in Tables 1 and 2 are the averages of three days' samples. Since particles collected on stages 2 and 3 $\left(D_{\mathrm{p}}: 10-2.5 \mu \mathrm{m}\right.$ and $2.5-1.0 \mu \mathrm{m}$, respectively) of the Dekati impactor were analyzed, the statistics in this article were for particles with a diameter in the range of 1.0-10 $\mu \mathrm{m}$. Four major particle types were encountered in the indoor subway environment: Fe-containing; soil-derived; carbonaceous; secondary nitrate and/ or sulfate particles. The Fe-containing particles were the most prevalent in the underground subway stations, with relative abundances of $38-88 \%$. Outdoor aerosol samples also contained a considerable amount of $\mathrm{Fe}$ containing particles with relative abundances of 15$26 \%$. Urban aerosol samples were reported to contain less than 5\% Fe-containing particles (Kang et al., 2009). Since the outdoor aerosol samples in this work were collected near the subway stations, the relatively high population of $\mathrm{Fe}$-containing particles in the outdoor samples was attributed to the influence of the indoor subway particles.

Distribution of the particle types were different among samples collected at various locations in the subway systems. In the Jegidong station (see Table 1 ), the relative abundance of $\mathrm{Fe}$-containing particles in the tunnel was as high as $85-88 \%$. The populations of Fe-containing particles decreased as the distance of the sampling sites increased from the tunnel, 79-83 $\%$ at the platform and $62-67 \%$ in the ticket office. A similar trend was observed at the Yangjae station samples. The relative abundance of Fe-containing particles for the samples collected in the tunnel, at the platform, 
Table 1. Average relative abundances of the particle types observed in the Jegidong station. The average relative abundances (\%), together with relative standard deviations, are for three samples collected for three consecutive days. Particle size ranges for stages 2 and 3 are $10-2.5$ and $2.5-1.0 \mu \mathrm{m}$, respectively.

\begin{tabular}{|c|c|c|c|c|c|c|c|c|}
\hline \multirow{2}{*}{ Particle types } & \multicolumn{2}{|c|}{ Tunnel } & \multicolumn{2}{|c|}{ Platform } & \multicolumn{2}{|c|}{ Ticket office } & \multicolumn{2}{|c|}{ Outdoor } \\
\hline & Stage 2 & Stage 3 & Stage 2 & Stage 3 & Stage 2 & Stage 3 & Stage 2 & Stage 3 \\
\hline Iron-containing & $\begin{array}{c}87.9 \\
( \pm 1.7 \%)\end{array}$ & $\begin{array}{c}84.7 \\
( \pm 4.2 \%)\end{array}$ & $\begin{array}{c}82.7 \\
( \pm 1.5 \%)\end{array}$ & $\begin{array}{c}79.2 \\
( \pm 1.1 \%)\end{array}$ & $\begin{array}{c}66.7 \\
( \pm 16.5 \%)\end{array}$ & $\begin{array}{c}62.0 \\
( \pm 9.6 \%)\end{array}$ & $\begin{array}{c}26.7 \\
( \pm 42.1 \%)\end{array}$ & $\begin{array}{c}15.3 \\
( \pm 84.4 \%)\end{array}$ \\
\hline Carbonaceous & $\begin{array}{c}3.6 \\
( \pm 3.2 \%)\end{array}$ & $\begin{array}{c}8.4 \\
( \pm 42.2 \%)\end{array}$ & $\begin{array}{c}4.9 \\
( \pm 56.2 \%)\end{array}$ & $\begin{array}{c}11.1 \\
( \pm 14.1 \%)\end{array}$ & $\begin{array}{c}13.8 \\
( \pm 57.4 \%)\end{array}$ & $\begin{array}{c}21.4 \\
( \pm 20.3 \%)\end{array}$ & $\begin{array}{c}15.8 \\
( \pm 34.8 \%)\end{array}$ & $\begin{array}{c}50.7 \\
( \pm 26.2 \%)\end{array}$ \\
\hline Soil-derived (sum) & $\begin{array}{c}4.9 \\
( \pm 9.7 \%)\end{array}$ & $\begin{array}{c}2.5 \\
( \pm 29.0 \%)\end{array}$ & $\begin{array}{c}9.5 \\
( \pm 46.7 \%)\end{array}$ & $\begin{array}{c}6.5 \\
( \pm 32.8 \%)\end{array}$ & $\begin{array}{c}11.8 \\
( \pm 49.7 \%)\end{array}$ & $\begin{array}{c}10.0 \\
( \pm 59.0 \%)\end{array}$ & $\begin{array}{c}31.0 \\
( \pm 21.7 \%)\end{array}$ & $\begin{array}{c}11.9 \\
( \pm 16.6 \%)\end{array}$ \\
\hline Aluminosilicates & 0.4 & 0.0 & 1.2 & 1.0 & 2.2 & 0.6 & 14.5 & 6.2 \\
\hline Aluminosilicates/C & 0.0 & 0.0 & 0.0 & 1.0 & 0.6 & 1.3 & 2.0 & 3.3 \\
\hline $\mathrm{CaCO}_{3}$ & 4.0 & 1.5 & 5.1 & 2.9 & 4.6 & 5.2 & 7.3 & 1.7 \\
\hline $\mathrm{CaCO}_{3} / \mathrm{C}$ & 0.4 & 0.0 & 0.0 & 0.3 & 2.9 & 1.7 & 0.0 & 0.0 \\
\hline $\mathrm{SiO}_{2}$ & 0.0 & 1.0 & 3.2 & 1.0 & 2.9 & 0.9 & 5.6 & 0.0 \\
\hline $\mathrm{SiO}_{2} / \mathrm{C}$ & 0.0 & 0.0 & 0.0 & 0.0 & 0.6 & 0.3 & 1.6 & 0.7 \\
\hline $\begin{array}{l}\text { Secondary nitrates/ } \\
\text { sulfates (sum) }\end{array}$ & $\begin{array}{c}0.9 \\
( \pm 141.4 \%)\end{array}$ & $\begin{array}{c}2.5 \\
( \pm 27.6 \%)\end{array}$ & $\begin{array}{c}2.3 \\
( \pm 66.0 \%)\end{array}$ & $\begin{array}{c}1.9 \\
( \pm 98.1 \%)\end{array}$ & $\begin{array}{c}6.8 \\
( \pm 88.0 \%)\end{array}$ & $\begin{array}{c}5.9 \\
( \pm 74.8 \%)\end{array}$ & $\begin{array}{c}23.4 \\
( \pm 61.3 \%)\end{array}$ & $\begin{array}{c}21.5 \\
( \pm 59.2 \%)\end{array}$ \\
\hline $\mathrm{Ca}\left(\mathrm{NO}_{3}, \mathrm{SO}_{4}\right)$ & 0.0 & 0.5 & 2.0 & 1.6 & 6.2 & 4.6 & 13.5 & 7.0 \\
\hline$(\mathrm{Na}, \mathrm{Mg})\left(\mathrm{NO}_{3}, \mathrm{SO}_{4}\right)$ & 0.9 & 2.0 & 0.3 & 0.3 & 0.6 & 1.3 & 9.6 & 13.8 \\
\hline$\left(\mathrm{NH}_{4}\right)_{2} \mathrm{SO}_{4}$ & 0.0 & 0.0 & 0.0 & 0.0 & 0.0 & 0.0 & 0.3 & 0.7 \\
\hline Others & 2.7 & 2.0 & 0.7 & 1.3 & 0.9 & 0.6 & 3.0 & 0.7 \\
\hline Total & 100 & 100 & 100 & 100 & 100 & 100 & 100 & 100 \\
\hline
\end{tabular}

Table 2. Average relative abundances of the particle types observed in the Yangjae station. The average relative abundances (\%), together with relative standard deviations, are for three samples collected for three consecutive days. Particle size ranges for stages 2 and 3 are $10-2.5$ and $2.5-1.0 \mu \mathrm{m}$, respectively.

\begin{tabular}{|c|c|c|c|c|c|c|c|c|}
\hline \multirow{2}{*}{ Particle types } & \multicolumn{2}{|c|}{ Tunnel } & \multicolumn{2}{|c|}{ Platform } & \multicolumn{2}{|c|}{ Ticket office } & \multicolumn{2}{|c|}{ Outdoor } \\
\hline & Stage 2 & Stage 3 & Stage 2 & Stage 3 & Stage 2 & Stage 3 & Stage 2 & Stage 3 \\
\hline Iron-containing & $\begin{array}{c}85.6 \\
( \pm 3.9 \%) \\
\end{array}$ & $\begin{array}{c}87.5 \\
( \pm 1.8 \%) \\
\end{array}$ & $\begin{array}{c}56.7 \\
( \pm 5.0 \%) \\
\end{array}$ & $\begin{array}{c}47.7 \\
( \pm 6.7 \%) \\
\end{array}$ & $\begin{array}{c}37.7 \\
( \pm 7.6 \%) \\
\end{array}$ & $\begin{array}{c}40.0 \\
( \pm 7.6 \%)\end{array}$ & $\begin{array}{c}20.1 \\
( \pm 44.8 \%)\end{array}$ & $\begin{array}{c}21.7 \\
( \pm 18.6 \%) \\
\end{array}$ \\
\hline Carbonaceous & $\begin{array}{c}4.6 \\
( \pm 61.5 \%) \\
\end{array}$ & $\begin{array}{c}6.7 \\
( \pm 63.0 \%) \\
\end{array}$ & $\begin{array}{c}21.3 \\
( \pm 13.7 \%) \\
\end{array}$ & $\begin{array}{c}29.6 \\
( \pm 1.8 \%) \\
\end{array}$ & $\begin{array}{c}26.7 \\
( \pm 10.2 \%) \\
\end{array}$ & $\begin{array}{c}21.9 \\
( \pm 32.6 \%) \\
\end{array}$ & $\begin{array}{c}29.9 \\
( \pm 2.3 \%)\end{array}$ & $\begin{array}{c}35.4 \\
( \pm 19.0 \%) \\
\end{array}$ \\
\hline Soil-derived (sum) & $\begin{array}{c}6.9 \\
( \pm 48.2 \%)\end{array}$ & $\begin{array}{c}4.2 \\
( \pm 28.7 \%)\end{array}$ & $\begin{array}{c}17.2 \\
( \pm 24.9 \%)\end{array}$ & $\begin{array}{c}10.7 \\
( \pm 12.4 \%)\end{array}$ & $\begin{array}{c}24.3 \\
( \pm 22.1 \%)\end{array}$ & $\begin{array}{c}20.5 \\
( \pm 7.3 \%)\end{array}$ & $\begin{array}{c}20.1 \\
( \pm 3.4 \%)\end{array}$ & $\begin{array}{c}16.2 \\
( \pm 37.9 \%)\end{array}$ \\
\hline Aluminosilicates & 2.0 & 0.6 & 2.6 & 1.0 & 8.7 & 6.6 & 11.3 & 9.3 \\
\hline Aluminosilicates/C & 0.0 & 0.3 & 0.7 & 3.2 & 1.3 & 2.3 & 0.0 & 0.0 \\
\hline $\mathrm{CaCO}_{3}$ & 1.3 & 1.3 & 8.1 & 3.2 & 6.2 & 4.0 & 2.5 & 2.5 \\
\hline $\mathrm{CaCO}_{3} / \mathrm{C}$ & 0.3 & 0.3 & 1.0 & 0.6 & 1.6 & 1.0 & 0.0 & 0.0 \\
\hline $\mathrm{SiO}_{2}$ & 2.6 & 1.0 & 4.6 & 2.7 & 4.8 & 4.3 & 4.9 & 2.5 \\
\hline $\mathrm{SiO}_{2} / \mathrm{C}$ & 0.0 & 0.6 & 0.3 & 0.0 & 1.6 & 2.3 & 1.5 & 2.0 \\
\hline $\begin{array}{l}\text { Secondary nitrates/ } \\
\text { sulfates (sum) }\end{array}$ & $\begin{array}{c}1.3 \\
( \pm 86.6 \%)\end{array}$ & $\begin{array}{c}0.7 \\
( \pm 86.6 \%)\end{array}$ & $\begin{array}{c}3.5 \\
( \pm 100.5 \%)\end{array}$ & $\begin{array}{c}8.8 \\
( \pm 21.8 \%)\end{array}$ & $\begin{array}{c}8.5 \\
( \pm 75.7 \%)\end{array}$ & $\begin{array}{c}14.2 \\
( \pm 51.6 \%)\end{array}$ & $\begin{array}{c}29.4 \\
( \pm 33.0 \%)\end{array}$ & $\begin{array}{c}25.7 \\
( \pm 71.2 \%)\end{array}$ \\
\hline $\mathrm{Ca}\left(\mathrm{NO}_{3}, \mathrm{SO}_{4}\right)$ & 1.3 & 0.7 & 2.5 & 7.5 & 6.5 & 8.6 & 18.6 & 13.3 \\
\hline$(\mathrm{Na}, \mathrm{Mg})\left(\mathrm{NO}_{3}, \mathrm{SO}_{4}\right)$ & 0.3 & 0.0 & 0.9 & 1.3 & 1.0 & 5.0 & 8.3 & 9.9 \\
\hline$\left(\mathrm{NH}_{4}\right)_{2} \mathrm{SO}_{4}$ & 0.0 & 0.0 & 0.0 & 0.0 & 1.0 & 0.6 & 2.5 & 2.5 \\
\hline Others & 1.6 & 1.0 & 1.3 & 3.2 & 2.9 & 3.0 & 0.5 & 1.0 \\
\hline Total & 100 & 100 & 100 & 100 & 100 & 100 & 100 & 100 \\
\hline
\end{tabular}

and near the ticket office at the Yangjae station were $86-88,48-57$, and $38-40 \%$, respectively. This obser- vation strongly suggests that the Fe-containing particles originated from the tunnel. 


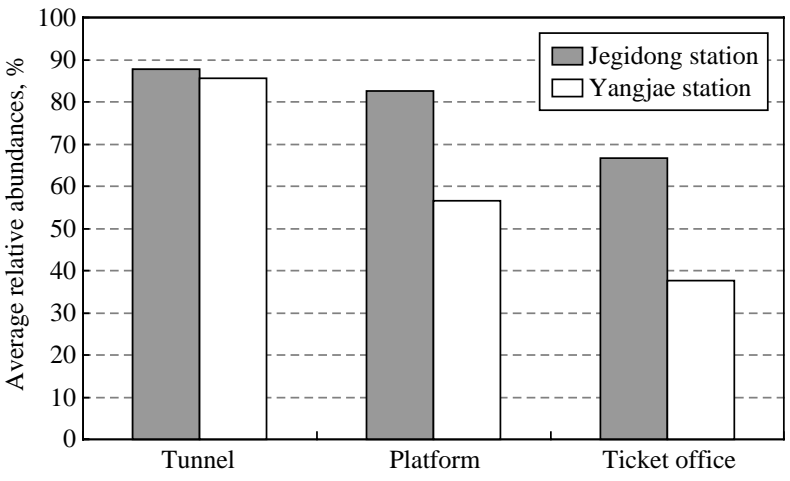

Fig. 2. Average relative abundances (\%) of Fe-containing particles for stage 2 samples collected in the Jegidong and Yangjae stations.

Furthermore, it was obvious that the relative abundance of Fe-containing particles at the platform in the Yangjae station (48-57\%) was much lower than that at the platform in the Jegidong station (79-83\%). This marked decrease of abundance of $\mathrm{Fe}$-containing particles at the platform in the Yangjae station was attributed to the existence of PSDs. The PSDs that separate the platform region from the tunnel limit the inflow of Fe-containing particles, generated in the tunnel, to the platform. As a result, a significant difference between the populations of $\mathrm{Fe}$-containing particles at the Jegidong and Yangjae stations can be seen in Fig. 2. Even though the populations of Fe-containing particles in the tunnels were nearly the same for both subway stations, the population of Fe-containing particles at the platform and the ticket office at the Yangjae station were smaller than those at the Jegidong station.

Comparing the results of this lab's previous study where the investigation of the wintertime subway particles at the Jegidong and Yangjae stations was performed (Jung et al., 2010), Fe-containing particles were observed less abundantly than those in the summer season samples in this work. For instance, at the Jegidong station, the relative abundance of the Fe-containing particles in the tunnel, at the platform, and at the ticket office were reported as 77-81, 71-77, 64-34\%, respectively, in this lab's previous work (Jung et al., 2010), smaller than those of the summertime subway samples shown in the work presented herein. This might be due to the limited air-exchange between the indoor subway system and the outdoor atmosphere because of the air-conditioning in the subway system during the summer. Adams et al. (2001) also reported the relatively high $\mathrm{Fe}$ concentrations during the summer in the underground subway system in London.

Soil-derived particles, such as aluminosilicates, $\mathrm{SiO}_{2}$, and $\mathrm{CaCO}_{3}$ were significantly encountered in subway samples, with relative amounts in the range of 2.5 to $24 \%$ (Tables 1 and 2). Furthermore, some of the soil-derived particles existed as internal mixes with carbonaceous species (denoted as aluminosilicates/C and $\mathrm{SiO}_{2} / \mathrm{C}$ ). In general, soil-derived particles are one of the most abundant aerosol types in the outdoor urban atmosphere, especially in the coarse fractions. The population of soil-derived particles in the subway environment increases as the sampling location approaches the entrance of the subway station. For instance, for the Jegidong stage 2 samples, the relative abundances of the soil-derived particles in the tunnel, at the platform, and near the ticket office were 4.9, 9.5, and $11.8 \%$, respectively. This implies that the soilderived particles flowed in from the outdoor environment by the commuters and by air-exchange between the indoor and outdoor environments.

Carbonaceous particles were significantly encountered in indoor subway samples, with their relative amounts ranging from 3.6 to $29.6 \%$ (Tables 1 and 2). Carbonaceous particles were abundant in the ambient urban atmosphere, especially in the fine fraction, sometimes constituting $\sim 50 \%$ of submicron tropospheric aerosols (De Gouw and Jimenez, 2009). As shown in Tables 1 and 2, for outdoor stage 3 samples, the relative abundance of carbonaceous particles ranged from 50.7 to $35.4 \%$, whereas for outdoor stage 2 samples, they ranged from 15.8 to $29.9 \%$. In the subway environment, the population of carbonaceous particles varied among the sampling sites, as did soil-derived particles. For the Jegidong stage 3 samples, the relative abundance of carbonaceous particles in the tunnel was $3.6 \%$ and increased as the sampling sites were located close to the outside; $4.9 \%$ at the platform and $13.8 \%$ at the ticket office. The trend clearly indicates that the carbonaceous particles arise from the outdoor environment.

Nitrate- and sulfate-containing particles, such as $\mathrm{Ca}\left(\mathrm{NO}_{3}, \mathrm{SO}_{4}\right),(\mathrm{Na}, \mathrm{Mg})\left(\mathrm{NO}_{3}, \mathrm{SO}_{4}\right)$, and $\left(\mathrm{NH}_{4}\right)_{2} \mathrm{SO}_{4}$ were observed in subway aerosol samples, with their relative abundances ranging from 0.9 to $14.2 \%$ (Tables 1 and 2). Particles denoted as $\mathrm{Ca}\left(\mathrm{NO}_{3}, \mathrm{SO}_{4}\right)$ are a mixture of $\mathrm{Ca}\left(\mathrm{NO}_{3}\right)_{2}$ and $\mathrm{CaSO}_{4}$ species, produced by the reaction of $\mathrm{CaCO}_{3}$ with nitrogen and sulfur oxide species (Hwang and Ro, 2006; Ro et al., 2005; Krueger et al., 2004). Similarly, sea-salts can react with nitrogen and sulfur oxide species in the air to produce nitrates and/or sulfates. Since genuine sea-salt particles contain a considerable amount of $\mathrm{MgCl}_{2}$, with mostly $\mathrm{NaCl}$, the aged (reacted) sea-salts are denoted as (Na, $\mathrm{Mg})\left(\mathrm{NO}_{3}, \mathrm{SO}_{4}\right)$ (Hwang and Ro, 2006; Ro et al., 2005; Laskin et al., 2003). These secondary particles (nitrates and/or sulfates) are also a common particle type in the outdoor atmosphere. As shown in Tables 1 and 2, the 
relative abundances of the secondary nitrate/sulfate particles gradually increase as the sampling locations approach the outside, indicating that these secondary particles in the subway environment might arise from the outdoor environment. However, since gaseous nitrogen and sulfur oxides are abundant in the indoor subway microenvironment, it is possible that such nitrates and sulfates can be formed by the reaction of $\mathrm{CaCO}_{3}$ and sea-salts flowing in from the outdoors with indoor gaseous nitrogen and sulfur oxides.

In order to compare indoor and outdoor aerosol compositions, outdoor aerosols were collected near subway station exits. For the outdoor aerosol samples, soilderived particles were the most abundant in stage 2 samples, and carbonaceous particles were the major particle types encountered in stage 3 samples (Tables 1 and 2). Secondary aerosols such as nitrate- and sulfate-containing particles were significant for both stage 2 and 3 samples, which were reaction products of $\mathrm{CaCO}_{3}$ or sea-salts with nitrogen or sulfur oxygen species. As mentioned earlier, observation of the relatively higher abundances (15-27\%) of Fe-containing particles in the outdoor aerosols collected near the station might be due to the Fe-containing particles emitted from indoors by the ventilation system.

\section{2 Iron-containing Subway Particles}

The Fe-containing particles were the most popular

Table 3. Average relative abundances $(\%)$ of iron-containing particle types observed in the Jegidong station samples.

\begin{tabular}{|c|c|c|c|c|c|c|c|c|}
\hline \multirow{2}{*}{ Iron species } & \multicolumn{2}{|c|}{ Tunnel } & \multicolumn{2}{|c|}{ Platform } & \multicolumn{2}{|c|}{ Ticket office } & \multicolumn{2}{|c|}{ Outdoor } \\
\hline & Stage 2 & Stage 3 & Stage 2 & Stage 3 & Stage 2 & Stage 3 & Stage 2 & Stage 3 \\
\hline $\mathrm{Fe}$ & 1.0 & 0.0 & 0.0 & 0.0 & 0.5 & 0.0 & 0.0 & 0.0 \\
\hline $\mathrm{Fe} / \mathrm{C}$ & 1.5 & 1.1 & 1.9 & 0.4 & 0.0 & 1.0 & 0.0 & 0.0 \\
\hline $\mathrm{Fe} / \mathrm{Ca} / \mathrm{C}$ & 0.0 & 0.0 & 0.0 & 0.0 & 0.0 & 0.0 & 0.0 & 0.0 \\
\hline $\mathrm{Fe} / \mathrm{FeO}_{\mathrm{x}} / \mathrm{C}$ & 1.5 & 0.0 & 0.8 & 0.4 & 0.5 & 1.7 & 0.0 & 0.0 \\
\hline $\mathrm{FeO}_{\mathrm{x}}$ & 0.5 & 0.0 & 0.0 & 0.0 & 0.0 & 0.0 & 0.0 & 0.0 \\
\hline $\mathrm{FeO}_{\mathrm{x}} / \mathrm{C}$ & 47.9 & 48.2 & 52.5 & 54.8 & 63.5 & 55.3 & 54.6 & 46.7 \\
\hline $\mathrm{FeO}_{\mathrm{x}} / \mathrm{Ca} / \mathrm{C}$ & 5.1 & 4.7 & 4.7 & 3.7 & 3.4 & 3.0 & 6.8 & 3.3 \\
\hline $\mathrm{FeO}_{\mathrm{x}} / \mathrm{Mg} / \mathrm{C}$ & 0.0 & 0.0 & 0.0 & 0.0 & 0.0 & 0.0 & 0.0 & 0.0 \\
\hline $\mathrm{FeO}_{x} / \mathrm{Mg} / \mathrm{Si} / \mathrm{C}$ & 0.0 & 3.0 & 0.0 & 0.0 & 0.0 & 1.0 & 0.0 & 0.0 \\
\hline $\mathrm{FeO}_{\mathrm{x}} / \mathrm{Si} / \mathrm{C}$ & 10.2 & 17.7 & 9.3 & 21.8 & 8.2 & 13.4 & 8.9 & 25.6 \\
\hline $\mathrm{FeO}_{\mathrm{x}} / \mathrm{Si} / \mathrm{Ba} / \mathrm{C}$ & 1.5 & 2.2 & 0.8 & 0.0 & 0.0 & 0.0 & 8.8 & 5.6 \\
\hline $\mathrm{FeO}_{\mathrm{x}} / \mathrm{Si} / \mathrm{Ca} / \mathrm{Ba} / \mathrm{C}$ & 4.1 & 2.9 & 0.4 & 2.9 & 2.0 & 1.9 & 5.0 & 5.6 \\
\hline $\mathrm{FeO}_{\mathrm{x}} / \mathrm{Si} / \mathrm{Ca} / \mathrm{C}$ & 24.9 & 19.5 & 27.7 & 14.3 & 19.7 & 22.7 & 12.6 & 11.1 \\
\hline $\mathrm{FeO}_{\mathrm{x}} / \mathrm{Si} / \mathrm{Ca} / \mathrm{Mg} / \mathrm{Ba} / \mathrm{C}$ & 0.0 & 0.0 & 0.4 & 0.0 & 2.1 & 0.0 & 0.0 & 0.0 \\
\hline $\mathrm{AlSi} / \mathrm{FeO}_{\mathrm{x}} / \mathrm{C}$ & 0.0 & 0.0 & 0.0 & 0.0 & 0.0 & 0.0 & 1.5 & 2.2 \\
\hline Total & 100.0 & 100.0 & 100.0 & 100.0 & 100.0 & 100.0 & 100.0 & 100.0 \\
\hline
\end{tabular}

Table 4. Average relative abundances (\%) of Fe-containing particle types observed in the Yangjae station samples.

\begin{tabular}{|c|c|c|c|c|c|c|c|c|}
\hline \multirow{2}{*}{ Iron species } & \multicolumn{2}{|c|}{ Tunnel } & \multicolumn{2}{|c|}{ Platform } & \multicolumn{2}{|c|}{ Ticket office } & \multicolumn{2}{|c|}{ Outdoor } \\
\hline & Stage 2 & Stage 3 & Stage 2 & Stage 3 & Stage 2 & Stage 3 & Stage 2 & Stage 3 \\
\hline $\mathrm{Fe}$ & 0.0 & 0.0 & 0.6 & 0.0 & 0.0 & 0.0 & 0.0 & 0.0 \\
\hline $\mathrm{Fe} / \mathrm{C}$ & 1.6 & 0.4 & 0.5 & 0.0 & 1.9 & 0.0 & 3.6 & 0.0 \\
\hline $\mathrm{Fe} / \mathrm{Ca} / \mathrm{C}$ & 0.4 & 0.4 & 0.0 & 0.0 & 0.0 & 0.0 & 0.0 & 0.0 \\
\hline $\mathrm{Fe} / \mathrm{FeO}_{\mathrm{x}} / \mathrm{C}$ & 0.0 & 0.0 & 0.0 & 0.0 & 0.0 & 0.0 & 0.0 & 0.0 \\
\hline $\mathrm{FeO}_{\mathrm{x}}$ & 0.0 & 0.0 & 0.0 & 0.0 & 0.0 & 0.0 & 0.0 & 0.0 \\
\hline $\mathrm{FeO}_{\mathrm{x}} / \mathrm{C}$ & 46.5 & 57.2 & 57.7 & 70.6 & 55.6 & 76.2 & 38.0 & 44.4 \\
\hline $\mathrm{FeO}_{\mathrm{x}} / \mathrm{Ca} / \mathrm{C}$ & 4.6 & 7.3 & 6.9 & 8.6 & 8.1 & 2.5 & 14.6 & 8.6 \\
\hline $\mathrm{FeO}_{\mathrm{x}} / \mathrm{Mg} / \mathrm{C}$ & 0.0 & 0.0 & 0.0 & 0.0 & 0.0 & 0.0 & 0.0 & 2.6 \\
\hline $\mathrm{FeO}_{\mathrm{x}} / \mathrm{Mg} / \mathrm{Si} / \mathrm{C}$ & 2.4 & 0.4 & 0.0 & 0.0 & 0.0 & 0.0 & 0.0 & 2.6 \\
\hline $\mathrm{FeO}_{\mathrm{x}} / \mathrm{Si} / \mathrm{C}$ & 12.5 & 12.1 & 10.8 & 8.7 & 13.3 & 12.3 & 18.3 & 18.5 \\
\hline $\mathrm{FeO}_{\mathrm{x}} / \mathrm{Si} / \mathrm{Ba} / \mathrm{C}$ & 0.0 & 0.7 & 1.7 & 3.0 & 0.8 & 1.7 & 1.9 & 2.0 \\
\hline $\mathrm{FeO}_{\mathrm{x}} / \mathrm{Si} / \mathrm{Ca} / \mathrm{Ba} / \mathrm{C}$ & 5.1 & 2.9 & 3.5 & 0.6 & 1.6 & 0.9 & 14.6 & 0.0 \\
\hline $\mathrm{FeO}_{\mathrm{x}} / \mathrm{Si} / \mathrm{Ca} / \mathrm{C}$ & 25.3 & 18.6 & 17.7 & 8.4 & 18.7 & 6.4 & 9.3 & 6.0 \\
\hline $\mathrm{FeO}_{\mathrm{x}} / \mathrm{Si} / \mathrm{Ca} / \mathrm{Mg} / \mathrm{Ba} / \mathrm{C}$ & 0.0 & 0.0 & 0.0 & 0.0 & 0.0 & 0.0 & 0.0 & 0.0 \\
\hline $\mathrm{AlSi} / \mathrm{FeO}_{\mathrm{x}} / \mathrm{C}$ & 0.0 & 0.0 & 0.5 & 0.0 & 0.0 & 0.0 & 0.0 & 15.2 \\
\hline Total & 100.0 & 100.0 & 100.0 & 100.0 & 100.0 & 100.0 & 100.0 & 100.0 \\
\hline
\end{tabular}


particle type in the subway environment, with several types of Fe-containing particles typically encountered, such as iron metal and partially or fully oxidized iron oxides. Most of the Fe-containing particles contained minor elements, such as $\mathrm{C}, \mathrm{N}, \mathrm{Mg}, \mathrm{Al}, \mathrm{Si}, \mathrm{S}$, and/or $\mathrm{Ca}$. When the atomic concentrations of those elements exceeded $10 \%$, the elements were regarded as a component of the particle. For example, the notation of " $\mathrm{FeO}{ }_{\mathrm{x}} / \mathrm{C} / \mathrm{Si} / \mathrm{Ca}$ " indicates that the particle was iron oxide internally mixed with $\mathrm{C}, \mathrm{Si}$, and $\mathrm{Ca}$ species. Tables 3 and 4 show the relative abundances of various kinds of Fe-containing particles observed at the Jegidong and Yangjae stations, respectively. Nearly 50\% of the Fe-containing particles were encountered as iron oxide containing $\mathrm{C}$ and approximately $20 \%$ of the Fe-containing particles were found iron oxide containing $\mathrm{Si}, \mathrm{Ca}$, and $\mathrm{C}$. Particularly, almost all of the Fe-containing subway particles were observed to contain $\mathrm{C}$ as a minor component (see the types of iron species in Tables 3 and 4). The major part of the $\mathrm{C}$ components in $\mathrm{Fe}$-containing particles must originate from the heterogeneous oxidation reaction between volatile organic carbons (VOCs) in the indoor subway environment and the active surface of Fe-containing particles when the particles were generated during the wear process (Kang et al., 2008). Si and Ca were quite common elements comprising Fe-containing particles. These elements probably originated from the brake blocks within the train, since brake blocks are composed of glass fiber and $\mathrm{CaCO}_{3}$. The friction between the rail and the brake blocks seem to generate iron oxide-containing $\mathrm{Si}$ and $\mathrm{Ca}$ elements. The components included in the Fe-containing subway particles depend on the compositions of the cast iron and brake block. For example, $\mathrm{Ba}$ was one of the frequently observed elements in the Tokyo subway system, as $\mathrm{BaSO}_{4}$ is used as a major constituent of brake blocks within that system (Furuya et al., 2001). Sitzmann et al. (1999) and Kang et al. (2008) have discussed the minor elements found in the subway particles in detail.

\section{CONCLUSIONS}

In this study, subway particles collected at two underground subway stations in Seoul, Korea, the Jegidong and Yangjae, were analyzed using low- $Z$ particle EPMA. Subway particles were collected at four different locations in the underground subway stations: in the tunnels; the platforms; near the ticket offices; and outdoors. The sampling scheme was designed to investigate indoor sources of subway particles and the difference in the chemical compositions between subway particles collected in stations with and without
PSDs. In the underground subway indoor environment, Fe-containing, soil-derived, carbonaceous, and nitrate/ sulphate particles were observed as major particle types. Among them, Fe-containing particles were the most popular with most of the Fe-containing particles found in oxidized forms. The research showed that the friction between the rail and the brake block of the wheel generated the $\mathrm{Fe}$-containing particles. The relative abundance of $\mathrm{Fe}$-containing particles showed a maximum in the tunnel (85-88\%), and gradually decreased as the sampling locations were further away from the tunnel. However, the relative abundances of particles of outdoor origins, such as aluminosilicate, $\mathrm{SiO}_{2}$, and carbonaceous particles, increased as the sampling locations approached closer to the outdoor environment. Based on these observations, it is confirmed that the Fe-containing particles in the subway stations were generated from the tunnel and outdoor originated particles in the subway stations were flowed in by human activities and the air-exchange between the underground subway system and outside air. The relative abundances of Fe-containing particles at the platforms were smaller for the samples collected in the Yangjae station with PSDs (48-58\% in the Yangjae station versus $79-83 \%$ in the Jegidong station), indicating that PSDs limit the inflow of the Fe-containing particles from the tunnel to the platform. Investigation of the subway particles using low- $Z$ particle EPMA provided detailed information on the chemical compositions as well as morphology of the subway particles. The authors contend that this information detailed herein will be useful in managing and controlling the air quality in underground subway environments.

\section{ACKNOWLEDGEMENTS}

This work was supported by the Seoul R\&BD Program (CS070160) and the Korea Science and Engineering Foundation (KOSEF) grant funded by the Korean government (MOST) (ROA-2007-000-20030-0).

\section{REFERENCES}

Aarnio, P., Yli-Tuomi, T., Kousa, A., Makela, T., Hirsikko, A., Hameri, K., Raisanen, M., Hillamo, R., Koskenralo, T., Jantunen, M. (2005) The concentrations and composition of and exposure to fine particles $\left(\mathrm{PM}_{2.5}\right)$ in the Helsinki subway system. Atmospheric Environment 39, 5059-5066.

Adams, H.S., Nieuwenhuijsen, M.J., Colvile, R.N. (2001) Determinants of fine particle $\left(\mathrm{PM}_{2.5}\right)$ personal exposure levels in transport microenvironments, London, UK. Atmospheric Environment 35, 4557-4566. 
Chillrud, S.N., Epstein, D., Ross, J.M., Sax, S.N., Pederson, D., Spengler, J.D., Kinney, P.L. (2004) Elevated airborne exposures of teenagers to manganese, chromium, and iron from steel dust and New York city's subway system. Environmental Science and Technology 36, $732-737$.

Choi, H.W., Hwang, I.J., Kim, S.D., Kim, D.S. (2004) Determination of source contribution based on aerosol number and mass concentration in Seoul subway stations. Journal of Korean Society for Atmospheric Environment 20, 17-31. (in Korean with English abstract)

De Gouw, J., Jimenez, J.L. (2009) Organic aerosols in the earth's atmosphere. Environmental Science and Technology 43, 7614-7618.

Furuya, K., Kudo, Y., Okinaga, K., Yamuki, M., Takahashi, S., Araki, Y., Hisamatsu, Y. (2001) Seasonal variation and their characterization of suspended particulate matter in the air of subway stations. Journal of Trace and Microprobe Techniques 19, 469-485.

Geng, H., Ryu, J., Jung, H., Chung, H., Ahn, K., Ro, C.-U. (2010) Single-particle characterization of summertime arctic aerosols collected at Ny-Alesund, Svalbard. Environmental Science and Technology 44, 2348-2353.

Hwang, H., Kim, H., Ro, C.-U. (2008) Single-particle characterization of aerosol samples collected before and during an Asian dust storm in Chuncheon, Korea. Atmospheric Environment 42, 8738-8746.

Hwang, H., Ro, C.-U. (2006) Direct observation of nitrate and sulfate from mineral dust and sea-salts using low$\mathrm{Z}$ particle EPMA. Atmospheric Environment 40, 38693880 .

Johansson, C., Johansson, P.-A. (2003) Particulate matter in the underground of Stockholm. Atmospheric Environment 37, 3-9.

Jung, H.J., Kim, B.H., Ryu, J.Y., Maskey, S., Kim, J.-C., Sohn, J.R., Ro, C.-U.(2010) Source Identification of particle matter collected at underground subway stations Seoul, Korea using quantitative single-particle analysis. Atmospheric Environment 44, 2287-2293.

Kang, S., Hwang, H., Kang, S., Park, Y., Kim, H., Ro, C.-U. (2009) Quantitative ED-EPMA combined with morphological information for the characterization of individual aerosol particles collected in Incheon, Korea. Atmospheric Environment 43, 3445-3453.

Kang, S., Hwang, H., Park, Y., Kim, H., Ro, C.-U. (2008) Chemical compositions of subway particles in Seoul, Korea determined by a quantitative single particle analysis. Environmental Science and Technology 42, 90519057.

Krueger, B.J., Grassian, V.H., Cowin, J.P., Laskin, A. (2004) Heterogeneous chemistry of individual mineral dust particles from different dust source regions: the importance of particle mineralogy. Atmospheric Environment 38, 6253-6261.

Laskin, A., Gaspar, D.J., Wang, W., Hunt, S.W., Cowin, J.P., Colson, S.D., Finlayson-Pitts, B.J. (2003) Reac- tions at interfaces as a source of sulfate formation in sea-salt particles. Science 301, 340-344.

Murruni, L.G., Solanes, V., Debray, M., Kreiner, A.J., Davidson, J., Davidson, M., Vazquez, M., Ozafran, M. (2009) Concentrations and elemental composition of particulate matter in the Buenos Aires underground system. Atmospheric Environment 43, 4577-4583.

Nieuwenhuijsena, M.J., Gomez-Perales, J.E., Colvile, R.N. (2007) Levels of particulate air pollution, its elemental composition, determinants and health effects in metro systems. Atmospheric Environment 41, 79958006.

Park, D.-U., Ha, K.-C. (2008) Characteristics of PM $\mathrm{PM}_{10}$, $\mathrm{PM}_{2.5}, \mathrm{CO}_{2}$ and $\mathrm{CO}$ monitored in interiors and platforms of subway train in Seoul, Korea. Environment International 34, 629-634.

Ro, C.-U., Hwang, H., Kim, H., Chun, Y., Van Grieken, R. (2005) Single-particle characterization of four Asian dust samples collected in Korea, using low-Z particle electron probe X-ray microanalysis. Environmental Science and Technology 39, 1409-1419.

Ro, C.-U., Kim, H.K., Van Grieken, R. (2004) An expert system for chemical speciation of individual particles using low-Z particle electron probe X-ray microanalysis data. Analytical Chemistry 76, 1322-1327.

Ro, C.-U., Osan, J., Szaloki, I., De Hoog, J., Worobiec, A., Van Grieken, R. (2003) A Monte Carlo program for quantitative electron-induced $\mathrm{X}$-ray analysis of individual particles. Analytical Chemistry 75, 851-859.

Ro, C.-U., Osan, J., Szaloki, I., Van Grieken, R. (2000) Determination of chemical species in individual aerosol particles using ultra-thin window EPMA. Environmental Science and Technology 34, 3023-3030.

Ro, C.-U., Osan, J., Van Grieken, R. (1999) Determination of low-Z EPMA elements in individual environmental particle using windowless EPMA. Analytical Chemistry $71,1521-1528$.

Salma, I., Weidinger, T., Maenhaut, W. (2009) Properties and sources of individual particles and some chemical species in the aerosol of a metropolitan underground railway station. Atmospheric Environment 43, 34603466.

Seaton, A., Cherrie, J., Dennekamp, M., Donaldson, K., Hurley, J.F., Tran, C.L. (2005) The London underground: dust and hazards to health. Occupational Environment and Medicine 62, 355-362.

Sitzmann, B., Kendal, M., Williams, I. (1999) Characterization of airborne particles in London computer-controlled scanning electron microscopy. Science of the Total Environment 241, 63-73.

Vekemans, B., Janssens, K., Vincze, L., Adams, F., Van Espen, P. (1994) Analysis of X-ray spectra by iterative least squares (AXIL): new developments. X-ray Spectrometry $23,178-285$.

(Received 10 March 2010, accepted 11 August 2010) 